\title{
PENGEMBANGAN PERANGKAT PEMBELAJARAN MATEMATIKA DENGAN PENDEKATAN PROBLEM BASED LEARNING UNTUK MENINGKATKAN KETERAMPILAN HIGHER ORDER THINKING
}

\author{
MATHEMATICAL LEARNING DEVELOPMENT DEVELOPMENT \\ WITH A PROBLEM BASED LEARNING APPROACH \\ TO IMPROVE SKILLS HIGHER \\ ORDER THINKING
}

\author{
ISNANI NURAMINAH SIMATUPANG ${ }^{1}$, LILY ROHANITA HASIBUAN², IRMAYANTI ${ }^{3}$ \\ ${ }^{123}$ Program Studi Pendidikan Matematika, FKIP Universitas Labuhanbatu \\ Jalan Sisingamangaraja No. 126A, KM. 3,5 Aek Tapa Rantauprapat \\ email:1isnanisimatupang@gmail.com,2Irohanita30@gmail.com,3irmayantiritonga2@gmail.com
}

\begin{abstract}
Abstrak
Penelitian ini bertujuan Untuk mengetahui: 1) Untuk mengetahui penggunaan perangkat pembelajaran matematika dapat meningkatkan keterampilan Higher Order Thinking siswa kelas VII MTs.S Islamiyah Batu Ajo pada materi pola bilangan Tahun Ajaran 2018/2019, dan 2) Untuk mengetahui penggunaan perangkat pembelajaran matematika dengan menggunakan Problem Based Learning pada materi pola bilangan Tahun Ajaran 2018/2019. Populasi adalah seluruh siswa kelas VII MTs Swasta Islamiyah Batu Ajo yang terdiri dari 2 kelas, yaitu kelas $\mathrm{VII}^{1}$ berjumlah 26 siswa dan kelas VII ${ }^{2}$ berjumlah 27 siswa, jumlah keseluruhan siswa kelas VII adalah 53 siswa. Sampel adalah kelas VII-1 yang berjumlah 26 siswa sebagai kelas eksperimen dan kelas $\mathrm{VII}^{-2}$ yang berjumlah 27 siswa sebagai kelas kontrol. Instrumen penelitian berupa tes uraian sebanyak 5 soal, angket sebanyak 10 pernyataan, dan observasi. Hasil data rata-rata pretest kelas eksperimen adalah 10.27, standart deviasi yaitu 2.585 dan varians yaitu 6.685. Rata-rata post-test dikelas eksperimen adalah 11,19, standart deviasi yaitu 3,522 dan varians yaitu 12,402. Dan nilai rata-rata posttets kelas kontrol adalah 69,69. Respon siswa terhadap keterampilan higher order thinking dirata-ratakan untuk pernyataan positif sebesar 74 dengan persentasi $41 \%$ (cukup). Respon siswa terhadap keterampilan higher order thinking dirata-ratakan untuk pernyataan negatif sebesar 35 dengan persentasi 19,4\% (sangat lemah). Jadi, kesimpulan respon siswa terhadap keterampilan higher order thinking dikategorikan menjadi cukup. Berdasarkan hasil penelitian disimpulkan bahwa Terdapat Pengembangan Perangkat Pembelajaran Matemetika Dengan Pendekatan Problem Based Learning Untuk Meningkatkan Keterampilan Higher Order Thinking Tahun Ajaran 2018/2019. Berdasarkan hasil penelitian diperoleh nilai rata-rata pretest dan posttest adalah 11,19 dan 10,27 dan uji t-test diperoleh nilai thitung sebesar -1,183, dan tabel sebesar 1,708 dengan tingkat signifikan 0,05, maka Ho ditolak dan $\mathrm{Ha}$ diterima. Artinya, ada pengembangan perangkat pembelajaran matematika dengan pendekatan problem based learning untuk meningkatkan keterampilan higher order thinking
\end{abstract}

\section{Kata Kunci: $\quad$ Higher Order Thinking, Problem based Learning}

\section{Abstract}

This study aims to: 1) to find cut the use of mathematies learning devics can improve higher order thinking skills of VII MTs.S Islamiyah Batu ajo class students on the material pattern of the number in $2018 / 2019$ school year, and 2) to find out the use of mathematics learning devices by using problem based learning on the material in 2018/2019 school year. The populations is all students of class VII MTs Swasta Islamiyah Batu Ajo that from two classes, is class $\mathrm{VII}^{-1}$ amounting to 26 students and class $\mathrm{VII}^{-2}$ totaling 27 students, the total number of class VII students is 53 students. The sample is class $\mathrm{VII}^{-1}$ which amounts to 26 students as an experimental class and class $\mathrm{VII}^{-2}$ which amounts to 27 students as a control class. The research instrument consisted of 5 questions, 10 questionnaires, and

Isnani Nuraminah Simatupang ${ }^{1}$, Lili Rohanita Hasibuan ${ }^{2}$, Irmayanti ${ }^{3}$

Pengembangan Perangkat Pembelajaran Matematika dengan Pendekatan Problem Based Learning untuk Meningkatkan Keterampilan High Order Thinking 
observations. The data results of average pretest of the experimintal class were 10,27 , the standart deviasi was 2,585 and the variance was 6,685 , the average posttest in the experimental class was 11,19 , the standart deviasi was 3,522 and the variance was 12,402 and average value of the posttest in the control class was 69,69 . Students responses to higher order thinking skills are averaged for positive statements of 74 with a percentage of $42 \%$ (enough). Students responses to higher order thinking skills are averaged for negative statements of 35 with a percentage of $19,4 \%$ (very weak). So, to conclusion of students responses to higher order thinking skills is categorized as sufficlent. Based on the results of the study concluded that there is a development of mathematics learning tools with a problem based learning approach to improve higher order thinking skills in 2018/2019 school year. Based on the results of the study obtained the average value of pretest and posttest is 11,19 and 10,27 and the t-test is obtained value og $-1,183$ and t table is 1,708 , with a significance level of 0,05 , then $\mathrm{Ho}$ is rejected and $\mathrm{Ha}$ is accepted. This means that there is a development of mathematics learning tools with a problem based learning approacesh to improve higher order thinking.

\section{Keywords: Higher Order Thinking, Problem based Learning.}

\section{Pendahuluan}

Pembelajaran mengandung makna adanya kegiatan mengajar dan belajar, di mana pihak yang mengajar adalah guru dan yang belajar adalah siswa yang berorientasi pada kegiatan mengajarkan materi yang berorientasi pada pengembangan pengetahuan, sikap, dan keterampilan siswa sebagai sasaran pembelajaran. [4] mengatakan, "pembelajaran bukanlah aktivitas, sesuatu yang dilakukan oleh seseorang ketika ia tidak melakukan aktivitas yang lain. Sedangkan menurut Undang-undang Sistem Pendidikan Nasional Nomor 20 tahun 2003 menyatakan bahwa "pembelajaran adalah proses interaksi peserta didik dengan pendidik dan sumber belajar pada suatu lingkungan belajar".

Matematika merupakan ilmu universal yang mendasari perkembangan teknologi modern, mempunyai peran penting dalam berbagai disiplin ilmu dan memajukan daya pikir manusia. Perkembangan pesat bidang teknologi informasi dan komunikasi dewasa ini dilandasi oleh perkembangan matematika di bidang teori bilangan, aljabar, analisis, teori peluang dan matematika diskrit. Untuk menguasai dan menciptakan teknologi masa depan diperlukan penguasaan konsepkonsep matematika yang baik sejak dini. [5] mengatakan, proses pembelajaran matematika di sekolah masih menggunakan pendekatan tradisional atau mekanistik, yakni seorang guru secara aktif mengajarkan matematika, kemudian memberikan contoh dan latihan, siswa berfungsi seperti mesin, siswa mendengar, mencatat, dan mengerjakan latihan.

Pengembangan perangkat pembelajaran adalah serangkaian proses atau kegiatan yang dilakukan untuk menghasilkan suatu perangkat pembelajaran berdasarkan teori pengembangan yang telah ada. Menurut [3] perangkat pembelajaran adalah sekumpulan sumber belajar yang memungkinkan guru dan siswa melakukan kegiatan pembelajaran. Perangkat pembelajaran yang dimaksud adalah Rencana Pelaksanaan Pembelajaran (RPP). Oleh karena itu, untuk mencapai tujuan pembelajaran diperlukan suatu perangkat pembelajaran sebagai alat yang digunakan oleh guru dalam melaksanakan pembelajaran di kelas.

Pendekatan pembelajaran berbasis masalah adalah model pembelajaran dengan pendekatan pembelajaran siswa pada masalah autentik sehingga siswa dapat menyusun pengetahuannya sendiri, menumbuhkembangkan keterampilan yang lebih tinggi dan inkuiri, memandirikan siswa, dan meningkatkan kepercayaan diri sendiri [2]. Model ini bercirikan penggunaan masalah kehidupan nyata sebagai sesuatu yang harus dipelajari siswa untuk melatih dan meningkatkan keterampilan berfikir tingkat tinggi dan memecahkan masalah, serta mendapatkan pengetahuan konsep-konsep penting, di mana tugas guru harus memfokuskan diri untuk membantu siswa mencapai keterampilan mengarahkan diri. Pembelajaran berbasis masalah penggunaannya di dalam tingkat berfikir yang lebih tinggi, dalam situasi berorientasi pada masalah, termasuk bagaimana belajarnya.

[1] mendefinisikan higher order thinking yaitu memberikan pemikiran yang kompleks, tidak ada algoritma untuk menyelesaikan suatu tugas, ada yang tidak dapat diprediksi, menggunakan pendekatan yang berbeda dengan tugas yang telah ada dan berbeda dengan contoh-contoh yang telah diberikan. Keterampilan berpikir tingkat tinggi (Higher Order Thinking Skill atau HOTS) yang meliputi menganalisis, mengevaluasi dan mengkreasi/mencipta. Higher Order Thinking ini akan lebih bagus jika dikaitkan dengan Problem Based Learning (PBL) karena pola berpikir tingkat tinggi adalah mampu menyelesaikan masalah. Dengan pendekatan higher order thinking siswa dapat diajak untuk aktif berpikir sehingga mereka juga aktif belajar, khususnya dalam pemecahan masalah.

Isnani Nuraminah Simatupang ${ }^{1}$, Lili Rohanita Hasibuan ${ }^{2}$, Irmayanti ${ }^{3}$

Pengembangan Perangkat Pembelajaran Matematika dengan Pendekatan Problem Based Learning untuk

Meningkatkan Keterampilan High Order Thinking 
Materi Pola Bilangan adalah salah satu materi yang dipelajari siswa kelas VII. Seperti pembelajaran matematika pada umumnya, pembelajaran materi ini masih konvensional. Sejalan dengan perubahan paradigma pembelajaran masa kini, pembelajaran geometri dalam hal ini materi pola bilangan hendaklah dilakukan secara konstruktif. Materi pola bilangan adalah salah satu materi yang perlu dipelajari untuk mengembangkan daya imajinasi siswa. Daya imajinasi berperan dalam membentuk keterampilan higher order thinking.

Berdasarkan latar belakang diatas maka identifikasi masalah dalam penelitian ini sebagai berikut : 1.) Kurangnya keterampilan dalam pelajaran matematika yang menyebabkan kecenderungan siswa lebih bersifat pasif. 2.) Kurang berani menyampaikan pendapat. 3.)Lemah dalam menyimpulkan asumsi. 4.) Kreatifitas siswa berkurang. 5.) Menurunnya keterampilan berpikir tingkat tinggi siswa. Dalam penelitian ini dirumuskan permasalahan sebagai berikut: 1.) Apakah penggunaan perangkat pembelajaran matematika dapat meningkatkan keterampilan Higher Order Thinking siswa kelas VII MTs.S Islamiyah Batu Ajo pada materi pola bilangan Tahun Ajaran 2018/2019. 2.) Bagaimana penggunaan perangkat pembelajaran matematika dengan pendekatan Problem Based Learning pada materi pola bilangan Tahun Ajaran 2018/2019.

\section{Metode Penelitian}

Populasi dalam penelitian ini adalah seluruh siswa kelas VII MTs Swasta Islamiyah Batu Ajo yang terdiri dari 2 kelas, yaitu kelas VII ${ }^{1}$ berjumlah 26 siswa dan kelas VII ${ }^{2}$ berjumlah 27 siswa. Jadi jumlah keseluruhan siswa kelas VII adalah 53 siswa. Sampel dalam penelitian ini adalah kelas VII-1 yang berjumlah 26 siswa sebagai kelas eksperimen dan kelas $\mathrm{VII}^{-2}$ yang berjumlah 27 siswa sebagai kelas kontrol.

Untuk memperoleh data yang dibutuhkan maka peneliti melakukan prosedur penenelitian sebagai berikut:

1. Tahap persiapan mencakup:

a.Mengembangkan perangkat pembelajaran (RPP, Silabus) yang dikonsultasikan kepada dosen pembimbing.

b. Menyusun instrumen penelitian

c. Pemilihan sampel penelitian

d. Melakukan uji coba instrumen

e. Menganalisis uji coba

2. Tahap Pelaksanaan mencakup:

a.Memberikan Tes untuk kelas Eksperimen dengan pembelajaran menggunakan pendekatan Problem Based Learning.

b. Memberikan Tes untuk kelas kontrol dengan pembelajaran menggunakan pembelajaran konvensional.

c. Memberikan angket kepada seluruh kelas VII.

d. Menghitung rata-rata angket setiap kelas.

3. Tahap Akhir mencakup:

1. Analisis data.

2. Hasil penelitian.

3. Kesimpulan.

Teknik pengumpulan data pada penelitian ini adalah sebagai berikut: 1. Observasi, 2. Tes, 3. Angket. Teknik analisis data bertujuan untuk memperoleh makna dari data yang telah terkumpul. Tahapan analisis yang dilakukan adalah sebagai berikut:

Untuk data kuantitatif dari hasil tes keterampilan Higher Order Thiking dilakukan analisis sebagai berikut. Uji persyaratan statistik terlebih dahulu sebagai dasar untuk pengujian hipotesis yaitu: uji normalitas dan uji homogenitas. Skala yang dapat digunakan untuk mengukur, pendapat, dan persepsi seseorang tentang suatu objek atau fenomena tertentu. Dengan menggunakan skala likert, maka variabel yang akan diukur dijabarkan menjadi dimensi, dimensi dijabarkan menjadi sub variabel kemudian sub variabel dijabarkan lagi menjadi indikator-indikator yang dapat diukur.

\section{Hasil Penelitian dan Pembahasan}

Validitas Tes

Istrumen dalam penelitian ini menggunakan instrumen tes dan angket dengan 26 siswa. Tes terdiri dari 8 soal uraian dan angket terdiri dari 10 item pernyataan kemudian di uji coba pada kelas $\mathrm{VII}^{-1}$ untuk di analisis sebagai berikut:

Isnani Nuraminah Simatupang ${ }^{1}$, Lili Rohanita Hasibuan², Irmayanti ${ }^{3}$

Pengembangan Perangkat Pembelajaran Matematika dengan Pendekatan Problem Based Learning untuk 
Tabel 4.1 Uji Validitas Tes

\begin{tabular}{ccc}
\hline Kategori & Butir & Jumlah \\
\hline Soal Valid & $1,2,3,4,5$ & 5 \\
Tidak valid & $6,7,8$ & 3 \\
Jumlah & & 8 \\
\hline
\end{tabular}

Dari 8 soal yang di validasi, diperoleh 5 soal yang valid, sedangkan 3 soal yang tidak valid tidak digunakan dalam penelitian.

Tabel 4.2 Uji Validitas Angket

\begin{tabular}{ccc}
\hline Kategori & Butir & Jumlah \\
\hline Soal Valid & $1,2,3,4,5,6,7,8,9$ & 9 \\
Tidak valid & 10 & 1 \\
Jumlah & & 10 \\
\hline
\end{tabular}

\section{Reliabelitas Tes}

Reliabelitas soal pada penelitian ini dihitung dengan menggunakan sofware versi 20. Kemudian peroleh rata-rata nilai $r_{\text {hitung }}$ sebesar 0,694 dan $\mathrm{N}=26(0,388)$, dimana $r_{\text {hitung }}>r_{\text {tabel }}=0,694$ $>0,388$. Maka instrumen penelitian ini dikatakan reliabel.

\section{Daya Pembeda}

Tabel 4.3 Daya Pembeda

\begin{tabular}{ccc}
\hline Kategori & Butir & Jumlah \\
\hline Sangat Baik & 1,3 & 2 \\
Baik & $2,4,5$ & 3 \\
Cukup & 7 & 1 \\
Sangat Jelek & 6,8 & 2 \\
Jumlah & & 8 \\
\hline
\end{tabular}

Berdasarkan perhitungan daya pembeda diperoleh soal sangat baik 2, soal baik 3 , soal cukup 1 , dan soal sangat jelek 2 .

\section{Tingkat Kesukaran}

\begin{tabular}{lll}
\multicolumn{3}{c}{ Tabel 4.4 Tingkat Kesukaran } \\
\hline Kategori & Butir & Jumlah \\
\hline Sedang & $1,2,3,5$ & 4 \\
Mudah & 4 & 1 \\
Jumlah & & 5 \\
\hline
\end{tabular}

Berdasarkan perhitungan tingkat kesukaran tes, maka diperoleh soal sedang sebanyak 4 , dan soal mudah sebanyak 1 .

\section{Hasil Pre-test Kelas Eksperimen}

Instrumen penelitian yang digunakan adalah tes keterampilan higher order thinking siswa yang terdiri dari 5 soal berbentuk uraian. Tes ini akan diuji cobakan oleh siswa sebelum pembelajaran tentang pokok bahasan pola bilangan. Hasil pre-test siswa seperti tabel berikut ini :

Tabel 4.5. Hasil Pretest Kelas Eksperimen Keterampilan Higher Order Thinking

\begin{tabular}{|c|c|c|}
\hline \multirow{2}{*}{ No. } & $\begin{array}{c}\text { Pemusatan dan } \\
\text { Penyebaran Data }\end{array}$ & Pretest \\
\cline { 3 - 3 } & & Eksperimen \\
\hline 1 & Mean & 10.27 \\
\hline 2 & Standart Deviasi & 2.585 \\
\hline 3 & Varians & 6.685 \\
\hline 4 & Skor Tertinggi & 14 \\
\hline
\end{tabular}

Isnani Nuraminah Simatupang ${ }^{1}$, Lili Rohanita Hasibuan ${ }^{2}$, Irmayanti ${ }^{3}$

Pengembangan Perangkat Pembelajaran Matematika dengan Pendekatan Problem Based Learning untuk 


\begin{tabular}{|r|r|r|}
\hline 5 & Skor Terendah & 6 \\
\hline
\end{tabular}

Berdasarkan tabel 4.5 diatas, berdasarkan perhitungan penelitian yang didapat dari pretest pada kelas $\mathrm{VII}^{-1}$ menunjukan bahwa skor tertinggi sebesar 14 dan skor terendah sebesar 6 . Nilai rata-rata yaitu 10.27, standart deviasi yaitu 2.585 dan varians yaitu 6.685 .

\section{Hasil Post-test Kelas Eksperimen}

Berdasarkan hasil tes yang diberikan kepada siswa di kelas eksperimen dengan menggunakan pendekatan Problem Based Learning dengan jumlah siswa sebanyak 26 orang, maka diperoleh deskripsi data hasil posttest sebagai berikut :

Tabel 4.6 Hasil Post-Tes Kelas Eksperimen Keterampilan Higher Order Thinking

\begin{tabular}{|c|c|}
\hline $\begin{array}{c}\text { Interval dan } \\
\text { Penyebaran Data }\end{array}$ & \begin{tabular}{c} 
Jumlah atau Nilai \\
\hline Mean
\end{tabular} \\
\hline Standar Deviasi & 11.19 \\
\hline Varians & 3.522 \\
\hline Skor Tertinggi & 12.402 \\
\hline Skor Terendah & 18 \\
\hline
\end{tabular}

Berdasarkan deskripsi hasil data pada tabel 4.6 menunjukkan bahwa hasil post-test dikelas eksperimen dari 26 siswa dikelas $\mathrm{VII}^{-1}$ yang menggunakan pendekatan Problem Based Learning memperoleh dengan skor tertinggi sebesar 18 dan skor terendah sebesar 4. Nilai rata-rata sebanyak 11,19 , standart deviasi yaitu 3,522 dan varians yaitu 12,402 .

a. Uji Normalitas Tes Keterampilan Higher Order Thinking Table 4.7 Rekapitulasi Hasil Perhitungan Uji Normalitas

\begin{tabular}{|l|l|l|l|l|}
\hline Data & Kelas & Taraf Signifikan & Signifikan & Kesimpulan \\
\hline $\begin{array}{l}\text { Evaluasi } \\
\text { Akhir }\end{array}$ & $\mathrm{VII}^{-1}$ & $\alpha=0,05$ & 0,820 & $\begin{array}{l}\text { Ho diterima } \\
\text { (normal) }\end{array}$ \\
\hline
\end{tabular}

Berdasarkan table 4.7 diatas menunjukkan bahwa data nilai evaluasi akhir keterampilan Higher Order Thinking siswa yang menggunakan pendekatan problem based learning berdistribusi normal. Hal ini ditunjukkan dari nilai signifikan yang dihasilkan lebih besar dari taraf signifikan yaitu 0,05 .

Table 4.8 Rekapitulasi Hasil Perhitungan Uji Homogenitas

\begin{tabular}{|c|c|c|c|c|}
\hline Data & Kelas & $\mathrm{N}$ & Signifikan & Kesimpulan \\
\hline $\begin{array}{c}\text { Evaluasi } \\
\text { Akhir }\end{array}$ & VII $^{-1}$ & 26 & 0,182 & Homogen \\
\hline
\end{tabular}

Table 4.9 Rekapitulasi Hasil Perhitungan Uji t

\begin{tabular}{|c|c|c|c|c|}
\hline Data & Kelas & $\mathrm{N}$ & Signifikan & Kesimpulan \\
\hline $\begin{array}{c}\text { Evaluasi } \\
\text { Akhir }\end{array}$ & $\begin{array}{c}\text { VII }^{-1} \\
\text { (pretest \& posttest) }\end{array}$ & 26 & 0,248 & $\begin{array}{c}\text { Terdapat perbedaan } \\
\text { signifikan. }\end{array}$ \\
\hline
\end{tabular}

Berdasarkan table 4.9 hasil perhitungan uji t yang ditunjukkan pada table diatas diperoleh nilai signifikan 0,248 yang berarti lebih besar dari taraf signifikan yaitu 0,05 yang berarti terdapat perbedaan keterampilan higher order thinking dengan pendekatan problem based learning yang signifikan antara pre-test maupun post-test.

Hasil Angket Keterampilan Higher Order Thinking

Tabel 4.14 Rekapitulasi Pertanyaan Positif Respon Siswa

\begin{tabular}{|c|l|l|l|l|l|l|l|l|l|}
\hline Pernyataan & SS & S & RR & TS & STS & Jumlah & Dibagi & $\%$ & Criteria \\
\hline 1 & 24 & 30 & 16 & $\mathbf{1}$ & $\mathbf{0}$ & $\mathbf{7 1}$ & $\mathbf{1 8 0}$ & $\mathbf{3 9 , 4}$ & Lemah \\
\hline 2 & 20 & 39 & $\mathbf{1 2}$ & $\mathbf{2}$ & $\mathbf{0}$ & $\mathbf{7 3}$ & $\mathbf{1 8 0}$ & $\mathbf{4 0 , 5}$ & Cukup \\
\hline 3 & 16 & $\mathbf{3 6}$ & $\mathbf{1 6}$ & $\mathbf{2}$ & $\mathbf{0}$ & $\mathbf{6 8}$ & $\mathbf{1 8 0}$ & $\mathbf{3 8}$ & Cukup \\
\hline $\mathbf{4}$ & $\mathbf{2 0}$ & $\mathbf{3 9}$ & $\mathbf{1 4}$ & $\mathbf{1}$ & $\mathbf{0}$ & $\mathbf{7 4}$ & $\mathbf{1 8 0}$ & $\mathbf{4 1}$ & Cukup \\
\hline 5 & $\mathbf{2 8}$ & $\mathbf{3 9}$ & $\mathbf{1 2}$ & $\mathbf{0}$ & $\mathbf{0}$ & $\mathbf{7 9}$ & $\mathbf{1 8 0}$ & $\mathbf{4 4}$ & Cukup \\
\hline
\end{tabular}

Isnani Nuraminah Simatupang ${ }^{1}$, Lili Rohanita Hasibuan ${ }^{2}$, Irmayanti ${ }^{3}$

Pengembangan Perangkat Pembelajaran Matematika dengan Pendekatan Problem Based Learning untuk 


\begin{tabular}{|c|c|c|c|c|c|c|c|c|c|}
\hline 6 & 24 & 36 & 14 & 1 & 0 & 75 & 180 & 41,6 & Cukup \\
\hline 7 & 16 & 42 & 16 & 0 & 0 & 74 & 180 & 41 & Cukup \\
\hline 8 & 24 & 39 & 14 & 0 & 0 & 77 & 180 & 42,7 & Cukup \\
\hline 9 & 28 & 36 & 12 & 0 & 0 & 76 & 180 & 42 & Cukup \\
\hline & \multicolumn{5}{|c|}{ Jumlah } & 667 & & 370,2 & \\
\hline & \multicolumn{5}{|c|}{ Mean } & 74 & & 41 & \\
\hline
\end{tabular}

Berdasarkan data diatas dapat disimpulkan bahwa respon siswa terhadap keterampilan higher order thinking apabila dirata-ratakan untuk pernyataan positif sebesar 74 dengan persentasi $41 \%$. Hal ini menunjukkan kategori setuju dan respon siswa terhadap keterampilan higher order thinking tergolong baik karena siswa lebih aktif serta dapat lebih memahami materi pembelajaran terutama pada pokok bahasan pola bilangan.

Tabel 4.15 Rekapitulasi Pertanyaan Negatif Respon Siswa

\begin{tabular}{|c|c|c|c|c|c|c|c|c|c|}
\hline Pernyataan & SS & S & RR & TS & STS & Jumlah & Dibaai & $\%$ & Criteria \\
\hline \multirow[t]{3}{*}{10} & 0 & 8 & 18 & 9 & 0 & 35 & 180 & 19,4 & Sangat \\
\hline & \multicolumn{5}{|c|}{ Jumlah } & 35 & & 19,4 & \\
\hline & \multicolumn{5}{|c|}{ Mean } & 35 & & 19.4 & \\
\hline
\end{tabular}

Berdasarkan data diatas dapat disimpulkan bahwa respon siswa terhadap keterampilan higher order thinking apabila dirata-ratakan untuk pernyataan negatif sebesar 35 dengan persentasi $19,4 \%$. Hal ini menunjukkan kategori setuju dan respon siswa terhadap keterampilan higher order thinking tergolong tidak baik karena siswa cepat merasa bosan dengan materi pembelajaran terutama pada pokok bahasan pola bilangan.

\section{Kesimpulan}

Berdasarkan hasil penelitian dan pembahasan yang telah diuraikan, maka dapat disimpulkan bahwa dari hasil tes perhitungan keterampilan higher order thinking siswa yang diajarkan dengan menggunakan pendekatan problem based learning, dapat terlihat peningkatan antara nilai rata-rata pretest dengan nilai rata-rata posttest yaitu 10,27 dan 11,19 . Hal ini terlihat bahwa nilai rata-rata pretest lebih kecil dikarenakan belum diberikan materi dibandingkan dengan nilai rata-rata posttest yang tinggi karena sudah mendapatkan materi pola bilangan menggunakan pendekatan problem based learning. Berdasarkan hasil penelitian diperoleh nilai rata-rata pretest dan posttest adalah 11,19 dan 10,27 dan uji t-test diperoleh nilai thitung sebesar -1,183, dan ttabel sebesar 1,708 dengan tingkat signifikan 0,05 , maka Ho ditolak dan Ha diterima. Artinya, ada pengembangan perangkat pembelajaran matematika dengan pendekatan problem based learning untuk meningkatkan keterampilan higher order thinking. Hal ini mengindikasikan bahwa terdapat pengembangan perangkat pembelajaran matematika dengan pendekatan problem based learning untuk meningkatkan keterampilan higher order thinking.

Hasil rekapitulasi respon siswa pada penelitian ini digunakan sepuluh butir pernyataan yang terdiri dari sembilan butir pernyataan positif dan satu butir pernyataan negatif. Kesepuluh butir pernyataan dianalisis menggunakan skala likert. Dan terlihat bahwa respon siswa dengan pernyataan positif secara keseluruhan menunjukkan kriteria cukup (setuju) dengan nilai rata-rata 74 dan persentasi sebesar $41 \%$. Sedangkan untuk pernyataan negatif secara keseluruhan menunjukkan kriteria sangat lemah (tidak setuju) dengan nilai rata-rata 35 dan persentasi sebesar $19,4 \%$. Hal ini menunjukkan bahwa respon siswa terhadap keterampilan higher order thinking tergolong tidak baik terutama pada materi pola bilangan.

\section{Daftar Pustaka}

[1] Arifin, R \& Heri, R. 2014. Pengembangan Perangkat untuk Meningkatkan HOTS pada Kompetensi Bangun Ruang Sisi Datar. Jurnal pendidikan Matematika Vol. 9 No. 2

[2] Etika P, Yusuf H, \& Ely S. 2016. Kemampuan Berpikir Tingkat Tinggi Siswa Kelas XI Dalam Pembelajaran Trigonometri Berbasis Masalah Di Sma Negeri 18 Palembang. JURNAL GANTANG Pendidikan Matematika FKIP Sriwijaya: Vol. 1 No. 1

[3] Hamdani. 2011. Startegi Belajar Mengajar. Bandung: Pustaka Setia.

[4] Hamruni. 2013. Strategi Pembelajaran. Yogyakarta: Insan Madani

Isnani Nuraminah Simatupang ${ }^{1}$, Lili Rohanita Hasibuan², Irmayanti ${ }^{3}$

Pengembangan Perangkat Pembelajaran Matematika dengan Pendekatan Problem Based Learning untuk

Meningkatkan Keterampilan High Order Thinking 
Jurnal Pembelajaran dan Matematika Sigma (JPMS)

Vol.5 (No.2) Nopember 2019

[5] Soedjani. 2006. IImu Pendidikan. Jakarta:Renika Cipta

[6] Sudianto. 2017. Keterampilan berpikir tingkat tinggi (HOTS)

Isnani Nuraminah Simatupang ${ }^{1}$, Lili Rohanita Hasibuan ${ }^{2}$, Irmayanti ${ }^{3}$

Pengembangan Perangkat Pembelajaran Matematika dengan Pendekatan Problem Based Learning untuk Meningkatkan Keterampilan High Order Thinking 